\title{
O Projeto de Extensão como Protagonista da Formação Ético- Humanística do Profissional de Saúde - Relato de Experiência
}

\author{
Oliveira, Bruna Miclos de; Duarte, Josiane Aparecida; Rodrigues, Fillipe Ferreira; Dantas, \\ Letícia Lopes; Gonçalves, Suziane Soares; Dias, Danilo Borges \\ Universidade Católica de Brasília — bruna.miclos@gmail.com
}

Introdução: um dos objetivos da educação do futuro profissional de saúde é dar ênfase a humanização, isso porque, com o aumento da demanda de serviços e com o excesso de tecnologias, esse ponto essencial perdeu espaço e muitas vezes é esquecido. Os projetos de extensão se tornaram maiores dentro das universidades, trazendo mais humanização para a formação dos profissionais. Dentre eles se encontra um projeto que auxilia uma instituição que abriga e presta assistência a portadores do vírus HIV e seus familiares. Objetivo: Expor o projeto que auxilia na superação de dificuldades relacionadas à área de saúde na comunidade e refletir sobre o aprendizado humanista que transforma o método de realizar o atendimento em saúde. Métodos: a base para a realização deste trabalho foi um projeto de extensão que teve como resultado o início de um aprendizado de respeito e acolhimento do desconhecido que só poderia ser adquirido por meio desta interação. Resultados: a aproximação dos acadêmicos com a comunidade não foi uma tarefa fácil, por isso foi preciso mostrar que a base do projeto era justamente o processo de humanização. a interação começou com atividades recreativas com as crianças, para que, posteriormente, com o apoio da coordenação da comunidade, fosse estabelecido um esquema de visitas das residências. nas visitas, uma pesquisa era feita procurando saber o que esperavam deste trabalho, em que se poderia acrescentar àquela sociedade e se eles participariam de atividades com os acadêmicos. a pesquisa trouxe uma noção um pouco mais profunda do que a sociedade quer do profissional de saúde, entendendo que a singularidade do indivíduo é uma exigência para que se possa humanizar na atenção à saúde, fazendo com que novas possibilidades sejam criadas para cada um. Além disso, trouxe a ética ao trabalho acadêmico dentro daquela pequena sociedade, procurando mostrar respeito e interesse por sua opinião. uma abordagem básica de atenção primária foi iniciada de forma conjunta. Desta forma, pequenas conversas sobre hipertensão, diabetes, métodos contraceptivos, prevenção de doenças eram discutidos e dúvidas eram tiradas, sempre recomendando a procura dos serviços de saúde. Conclusão: Percebe-se que a população não é apenas um consumidor de serviços de saúde e que para satisfazer e prestar um serviço de qualidade existe a necessidade de que o profissional de saúde entenda que não se pode tomar apenas como referência o diagnóstico, o tratamento, a etiologia, mas também é indispensável que a ética esteja presente, ou seja, a humanização é a resposta para que não apenas nos momentos em que se procura a população, mas naqueles em que eles se dirigem ao serviço de saúde, uma relação de acolhimento do desconhecido seja realizada, fazendo com que a segurança do paciente no profissional de saúde seja estabelecida.

Oliveira, Bruna Miclos de; Duarte, Josiane Aparecida; Rodrigues, Fillipe Ferreira; Dantas, Letícia Lopes; Gonçalves, Suziane Soares; Dias, Danilo Borges. O Projeto de Extensão como Protagonista da Formação Ético-Humanística do Profissional de Saúde - Relato de Experiência. In: Anais do Congresso Internacional de Humanidades \& Humanização em Saúde [= Blucher Medical Proceedings, num.2, vol.1]. São Paulo: Editora Blucher, 2014. ISSN 2357-7282

DOI 10.5151/medpro-cihhs-10699 